\title{
Professionals’ Dichotomous Take on Instructional Supervision Styles for Technical Institutions in Ghana
}

\author{
Quansah Joseph Y D, Lecturer \\ University for Development Studies, Faculty of Education, \\ Department of Educational Foundations, Tamale, Ghana \\ Gayomey John, Lecturer \\ Tamale Polytechnic, School of Business, \\ Accountancy Department, Tamale, Ghana.
}

\section{Attakora-Amaniampong Elvis, Lecturer}

University for Development Studies, Faculty of Planning and Land Management, Department of Real Estate and Land Management, Ghana

doi: 10.19044/esj.2016.v12n19p255 URL:http://dx.doi.org/10.19044/esj.2016.v12n19p255

\begin{abstract}
Learning is central to the purpose of a school and teaching is a basic tool to promote learning. This, then underlines the significance of instructional supervision and its types as magic bullet to effective teaching and learning in most educational institutions. However, contemporary research within the Ghanaian context is salient on the professionals' preferred supervision types in public technical educational institutions. This study employed a descriptive research survey design to accomplish this. Three set of questionnaires were developed after literature survey and data was collected from 502 participants consisting of 484 teachers, 9 circuit supervisors and 9 principals. These participants were selected based on a multi-stage sampling technique, from the nine Technical Institutions in the Greater Accra region. The data, mainly categorical in nature was analysed using mean and percentages with the aid of SPSS version 18. The findings of the study showed that teachers preferred instructional supervision that is premised on the mutual relationship between the teachers and the supervisors while principals and external supervisors preferred the formal rules-based supervision. This study suggests a hybrid instructional supervision which merges the two types of instructional supervision. The formal rules-based and collegial based types of instructional supervision should be blended, if teachers' performance are to be enhanced.
\end{abstract}

Keywords: Supervision, Collegial, Mutual Relationship, Formal Rule, Professional, Instructional and Dichotomous 


\section{Introduction}

The instructional delivery in the educational system in Ghana is fraught with countless of challenges. These challenges include teacher deficit, derisory infrastructure and quivering educational policies. In the midst of some of these challenges, a lot of stakeholders have always focused more on the academic performance of students, failing to have a spot on the other processes through which excellent students' academic performance is achieved. Technical education which is seen as a very important pillar in the development process of the country (Ghana) has a fair share of these challenges in the educational system. Public perception seems to indicate that the process of practical skills acquisition by students of technical institutes in Ghana is presently not operating to its full potential. Informal interactions with principals, teachers and students in the technical institutions suggested that one of the sources of the phenomenon is because instructional supervision is treated haphazardly in the technical institutions. Kpatakpa (2008) corroborated the above and opined that academic standards of students have fallen due to poor supervision reflecting in poor teacher performance in Ghana as supported by the finding of the Integrated Social Development Centre (ISODEC, 2011).

This is buttressed by related research findings (Opare, 1999; Oduro, 2008) which suggest that poor student performance in public schools, in part, is the result of ineffective supervision of teachers. This situation is disheartening; especially when one considers the fact that public technical institutes are staffed with more professional teachers than private ones. Therefore, discourse in the supervision of instruction in the educational system must not be treated lightly due to its consequences on academic performance. Many studies have been conducted on supervision in schools but, none of them touched on the preferred mode of supervision of teachers and the supervision used by principals and external supervisors in the Technical institutions. However research findings suggested that the improvement of teacher performance through effective supervision dependents upon teacher attitudes toward supervision. Unless teachers were satisfied with the supervision they received, it would not have the desired effects of promoting professional growth and improving student learning. It is against this background and its associated consequences that, this study was undertaken to ascertain information on the type of supervision to use to improve teachers' performance in the public technical institutes. Specifically, the study has a three-fold research objectives: first, to find out teachers' preference for instructional supervision styles in the Technical institutions; second, to find out principals' and external supervisors' preferred type of instructional supervision used in the Technical institutions; thirdly, to identify the type of instructional supervision styles used in the 
Technical Institutions. The study intends to help supervisors to become aware of the kind of supervision teachers would prefer which would contribute to improve their performance in the Technical institutions. This is because in the world over, there has been increasing research popularity concerning teacher performance improvement through supervision to enhance quality education.

This paper is organized as follows; it started with a brief introductory section. Then follows some literature review. Next, the research methodology of the paper are explained, followed by the results and discussion. Finally, conclusion and recommendations are considered.

\section{Literature Review}

Educational supervision is not only sensitive but also, a very broad subject. It is difficult to agree on one definition for educational supervision due to the varying content of its framework and differences in perception and orientation (Hismanoglu \& Hismanoglu 2010). According to Bamroongraks (1996:253), supervision, is understood as "the instructional improvement of schools and teachers". Earlier work of Daresh (2001) defines educational supervision to include all dynamic activities that aim at improving learning, studies and all other determinants of an educational situation. The definition of Daresh (2001) is too broad and simplistic in context. A straightforward and concise definition by Kilminster, Jolly \& Van der Vleuten (2007) define educational supervision as all guidance and feedback activities to develop a teacher as person, professional and educationist. Supervision is also defined as a tool for administrators in executing their daily responsibilities in individual or in group situations that include management, administration, evaluation and accountability; determination of ends, and the processes and evaluation of results (Nyarko, 2009). Ghana Education Service Inspectorate Division (2009) defines supervision of education as the activities carried out by supervisors to oversee the productivity/performance and achievement levels of employees (teachers, heads, other stakeholders) and learners with the aim of bringing about educational improvement. Supervision affects the teaching and learning process, curriculum organization, method of assessment and reporting, allocation of teaching materials, funds as well as motivation of both the teaching and non-teaching staff.

Campbell, Bridges \& Nystrand (1977) and Stevenson (2006); list the functions of supervision as planning, commanding, coordinating and controlling which was supported by Campbell et al, (1997). Hersey and Blanchard (1988) also identify the functions of supervision as managerial functions (planning, commanding, coordinating, assessing and controlling). As mentioned earlier, traditionally supervision is seen as inspectorial in 
nature (Richardson, 2003, Al-Hamdam and Al-Yacoub, 2005). Researchers have always maintained that leadership and supervision styles as a rule reflect the academic performance in schools.

In terms of source of authority, supervision could be categorized into two extreme types: the first type is supervision based on formal rules and second type of supervision is based on mutual relationships between the teachers and the supervisors. Supervision based on formal rules has theoretical underpinnings from the classical theorists who held the premise that formal rules in the form of strict supervision is the best way of achieving improvement. This supports Duffy's (1997) version of supervision which is based on rigid and formal supervision. However, this school of thought was opposed by writers like Baafi-Frimpong (2002) on the basis that teachers are professionals who are well-trained to do their work and do not need such a rigid and formal supervision. The second type of supervision which is based on mutual relationship between teachers and supervision is in line with collegial supervision. Collegial supervision is not mostly used by supervisors in schools. Thus, more than a few authorities in the area of supervision recommend collegial processes as options for supervision of teachers (Glatthorn, 1990; Sergiovanni \& Starratt, 1993; Sullivan \& Glanz, 2000). However, Sergiovanni \& Starratt (1993) believed that promoting collegiality among teachers is an important way to help schools change for the better. In their view, collegial supervision refers to "the existence of high levels of collaboration among teachers and between teachers and principals and is characterised by mutual respect, shared work values, cooperation, and specific conversations about teaching and learning” (Sergiovanni \& Starratt, 1993:103).

Again, Glatthorn (1990) explained the cooperative professional development as a process of fostering teacher growth through systematic collaboration with peers and includes a variety of approaches such as professional dialogue, curriculum development, peer observations and feedback, and action research projects. One key question that remains is how collegiality can promote effective academic performance. It is one thing having teachers and heads to work together and another thing directing that cooperation into best practices and good academic output. Even though this model may have its inherent weaknesses having to work in a group, Goldhammer (1980) stood by the conjecture that the most telling mark of any practitioner's commitment and fitness to perform professional work is the readiness to have such work examined and critiqued by other competent workers. However, some heads have been seen as very autocratic in their supervision, making all other players, including students taking the 'back seat'. Comparing the two can be very helpful since supervision is primarily 
concerned with improving classroom practices for the benefit of students regardless of what may be entailed (Bays, 2001).

\section{Supervision in the Ghana Education Service}

Early 2002 saw a single document of rich information on supervision by the name the "Circuit Supervisors`Handbook” in Ghana (GES, 2002). Supervision of instruction was addressed under the sub-headings of clinical and traditional supervision, traditional and clinical supervisors, communication, and its barrier and improvement were given. Furthermore, important issues such as improving school administration, gender issues in education, managing supervision and monitoring were covered. Other additional critical issues in this handbook included monitoring pupil performance, assessing teacher performance, managing in-service training, managing guidance and counseling, and school-community relationships (GES, 2002).

Currently, there are two documents with the Ghana Education Service Inspectorate Division which are of immense importance to this study. They are titled "Roles and Responsibilities Standards for Circuit Supervisors" and "Roles and Responsibilities Standards for Teachers". They were published in May and June, 2009 respectively.

In the "Roles and Responsibilities Standards for Circuit Supervisors" the professional skills and attributes required of supervisors are categorically listed in terms of school supervision, school management, school inspection and follow-ups, communication skills and positive personality traits (GES, 2009A). Likewise, the "Roles and Responsibilities Standards for Teachers" documents the required professional skills of all teachers which are listed in the spheres of professional attributes, planning, teaching and learning activities, and personal as well as professional development (GES, 2009B). These two documents are important as they highlighted the issues that form the subject matter of this research and give timely information relevant to the study.

\section{The effect of Teacher Performance on Students' Achievements}

Performance is referred to as the degree to which employees contribute to the attainment of the organizational goals (Thompson \& Srickland, 1995; Mankoe, 2007). The effect of teacher performance on student achievement is well established in the literature. Teacher performance has been identified as the most important variable in increasing student achievement by researchers (Feistritzer, 1999; Goldhaber and Brewer 1999 and Milken Family Foundation, 2000). Leigh and Mead (2005) also classify competence of teacher as the key determinant of achievements of school children. This view supports an earlier work from 
Izumu, Lance, Wlliam and Evers (1999, 2002), Vagas and Laat (2003), Rivkin, Hanushek and Kain (2004), and Hanushek (2005) who earlier held the view that knowledge and skills of teachers have immerse impact on children's achievements in school.

This is in line with the position of the Ghana Education Service (2002) which states that a key aspect of the head teachers' performance appraisal system is to improve their` professional and managerial skills to perform their duties well to realize the overall goal of achieving quality education in Ghana.

The Ghana Education Service (2002) measures teacher performance in the following areas: teachers doing their work professionally; performing their tasks to meet or surpass what is expected of them; teachers having selfconfidence; teacher being proficient in self-improvement and self-analysis. More importantly, teachers performance are assessed in the areas of personal data; record keeping; punctuality and attendance; communication skills; relationship with community; and personal traits (GES, 2002; 2009). In short, teacher performance is expressed in areas of competence such as instructional supervision, record keeping, punctuality, and attendance among others.

\section{Research Methodology}

A descriptive survey research design was appropriate with the use of questionnaire for the data collection from the nine Technical Institutions in the Greater Accra region of Ghana. Best and Khan (1998) explain descriptive research to be concerned with the conditions or relationships that exist, such as determining the nature of prevailing conditions, practices and attitudes; opinions that are held; processes that are going on; and/or trends that are developed. The population of this study included all staff, principals and supervisors of all the Technical Institutes in the Greater Accra Region. This is made up of nine technical institutions. The staff population was estimated at 750 with nine principals and nine external supervisors. The census sample technique was used for the principals, external supervisors and all the technical schools but quota sampling technique was used for teachers in the technical institutions. The sample size of 581 participants comprised of 9 circuit supervisors, 9 principals purposively selected and 563 teachers from the nine technical institutions in the study area. The 563 teachers were selected based on a quota and simple random sampling techniques.

Three set of questionnaires were developed by the researchers and were validated by some senior lecturers who are experts in the subject matter. Senior Lecturers comments and remarks were considered and incorporated to enhance the reliability of the questionnaires. Again, 581 
participants were targeted for teacher questionnaires, however, 502 of them effectively returned their questionnaires constituting a response rate of 86.4\%. The Statistical Product and Service Solutions (SPSS) version 18 software was employed in the analyses of data using frequency count, simple percentages and mean. Three set of questionnaires code named TQ (Teachers' questionnaire), PQ

(Principals' questionnaire) and ESQ (External supervisors' questionnaire) were administered to the Teachers, Principals and External Supervisors respectively. The reason for using these instruments were that they enabled the researchers to collect the needed data quickly.

\section{Findings and Discussion}

\section{Teachers Demographic Data}

Table 1 shows that (78)16.13\% of the teacher participants fell within the $20-29$ age group, $23.30 \%$ fell within the $30-39$ age group, $28.28 \%$ fell within the 40-49 age group and 32.29\% fell within the 50-59 age group. The implication of this information is that majority of teachers investigated are relatively young and have more years to serve in the institutions.

Table 1: Age distribution of Participants

\begin{tabular}{lcc}
\hline Age Distribution & Participants & Percentage (\%) \\
\hline $20-29$ & 78 & 16.13 \\
$30-39$ & 113 & 23.30 \\
$40-49$ & 137 & 28.28 \\
$50-59$ & 156 & 32.29 \\
\hline Total & 484 & 100 \\
\hline
\end{tabular}

Table 2 shows that none of the teacher participants had the $\mathrm{PhD}$ qualification. It also shows that $6.6 \%$ of the participants had the Diploma while $86.6 \%$ were holders of Bachelor degree and 6.7\% had Master's degree. This information reveals that in the Technical institutions, the number of teachers who had Bachelor degree qualification was quite significant. Table 2: Academic Qualifications of Teacher Participants

\begin{tabular}{lcc}
\hline \multicolumn{1}{c}{ Academic qualification } & Participants & Percentage (\%) \\
\hline Diploma & 32 & 6.6 \\
Bachelor & 419 & 86.6 \\
Masters & 33 & 6.8 \\
\hline
\end{tabular}

The implications is that there are more competent teachers and require little attention from supervisors to guide them on teaching skills. The other $6.7 \%$ of the participants hold the masters qualifications. This distribution has very important implications. It shows that the majority of teachers in the Technical institutions hold the required standard academic qualifications in the Greater Accra Region. 
Table 3 shows that 65 participants representing 13.3\% fell within the 6-15 years of experience group; 371 participants representing $76.7 \%$ had $16+$ years' experience as teachers. The implication of this information is that the majority of teachers investigated were more experienced. Altogether, 48 teachers, constituting $77.09 \%$ of the participants had less than ten years of working experience. Teachers with less experience like this group require more attention from the supervisors than the more experienced. Table 3: Working experience of Participants

\begin{tabular}{lcc}
\hline Experience & Participants & Percentage (\%) \\
\hline $0-5$ & 48 & 10.1 \\
$6-15$ & 65 & 13.3 \\
$16+$ & 371 & 76.6 \\
\hline
\end{tabular}

According to international literature, many teachers especially newly qualified may not have mastered sufficient skills for effective teaching. Hence, the need for instructional supervision (Beach et.al 1989). This inquiry suggests a strong relationship between instructional supervision and the quality of lesson delivery by teachers.

\section{Principals’ Demographic Data}

Table 4 shows that $77.2 \%$ of the participants were males and $22.8 \%$ females. The observation is that male dominated as principals in the Technical Institutions than their female counterparts. This information reveals gender imbalance because there are not enough qualified lady teachers in the Technical Institutions in the country. This supports the study conducted by Ndebele (2000) in Tsholotsho district of Zimbabwe which revealed that there were very few qualified lady teachers in Technical Institutes.

Table 4: Sex distribution of Principals

\begin{tabular}{lccc}
\hline SEX & Participants & & Percentage (\%) \\
Male & 7 & 77.2 \\
Female & 2 & 22.8 \\
\hline Total & $\mathbf{9}$ & $\mathbf{1 0 0}$ \\
\hline
\end{tabular}

Table 5 shows that none of the principals was less than 40 years. However, out of the nine principals contacted, 2 of them representing $22.2 \%$ are between ages of $40-49$ while 7 of them representing $77.8 \%$ are between ages of 50-59. The implication of this information is that majority of principals investigated are closer to their requirement. 
Table 5: Age distribution of Principals

\begin{tabular}{lcc}
\hline Age Distribution & Participants & Percentage (\%) \\
\hline $20-29$ & 0 & 0 \\
$30-39$ & 0 & 0 \\
$40-49$ & 2 & 22.2 \\
$50-59$ & 7 & 77.8 \\
\hline
\end{tabular}

Professionals' Preferred type of Instructional Supervision: The Principals, external supervisors and teachers preferred type of instructional supervision to be used in the Technical institutes are presented in tables 6 and 7.

Table 6 shows that a high number of 285 teacher participants representing 59\% disagreed to the assertion that supervision based on formal rules are most preferred while only 199 participants representing $43.19 \%$ of the teachers strongly agreed and agreed that supervision based on formal rules are most preferred. This finding supports the claim that the relationship between the teacher and the supervisor is expected to be collegial rather than authoritarian (Fraser 2000). However, all the 9 (100\%) supervisors and $9(100 \%)$ principals strongly agreed and agreed to the claim that supervision based on formal rules are the most preferred. This is buttressed by the claim that more than a few authorities in the area of supervision recommend collegial processes as options for supervision of teachers (Glatthorn, 1990; Sergiovanni \& Starratt, 1993; Sullivan \& Glanz, 2000). This is contrary to Al-Hamdam and Al-Yacoub (2005) claim that supervision in its modern perspective should be based on mutual relationship between the supervisors and the supervisee.

Table 6: Professionals’ Preference for Formal rules based supervision

\begin{tabular}{rcll}
\hline \multicolumn{2}{c}{ 484 Teachers } & \multicolumn{1}{c}{$\begin{array}{c}\text { 9 Principals } \\
\text { Mean = 1 }\end{array}$} & $\begin{array}{l}\text { 9 Supervisor } \\
\text { Mean }=1\end{array}$ \\
\cline { 2 - 3 } Rating & Frequency (\%) & Frequency (\%) & Frequency (\%) \\
S. A & $81(16.74 \%)$ & $9(100 \%)$ & $9(100 \%)$ \\
A & $118(26.45 \%)$ & 0 & 0 \\
D & $242(50 \%)$ & 0 & 0 \\
S. D & $43(6.81 \%)$ & 0 & 0 \\
\hline
\end{tabular}

Note: S.A =Strongly Agreed, A =Agreed, D = Disagreed and S.D = Strongly Disagreed

Table 7 shows that as high as 468 teachers strongly agreed and agreed to the assertion that supervision based on collegial supervision are most preferred with only 16 teachers disagreed. This supports Al-Hamdam and Al-Yacoub (2005) claim that supervision in its modern perspective should be based on mutual relationship between the supervisors and the supervisee. Sergiovanni \& Starratt (1993) on their part reiterate that promoting collegiality among teachers is an important way to help schools change for the better. This supports the views of Milken Family Foundation 
(2000), Feistritzer (1999), and Goldhaber and Brewer (1999) that teachers' performance is uncovered as the most vital variable in increasing students' achievements by researchers. Thus, majority of teachers preferred to be notified about the classroom visits as a formality so that the teacher would be aware that the supervisor would be coming observe the lesson. This finding tallies with Cogan (1973) who observed that it is important to create conditions that will make the teacher comfortable during the supervision process. For example, where the supervisor and the supervise have cordial relations, there are high chances of the teacher feeling comfortable during the supervision process.

Table 7: Professionals’ Preference for collegial supervision

\begin{tabular}{cccc}
\hline & $\begin{array}{l}\text { 484 Teachers } \\
\text { Mean }=1.8\end{array}$ & $\begin{array}{c}9 \\
\text { Assistants } \\
\text { Mean = 5 }\end{array}$ & $\begin{array}{l}\text { Principals } \\
\text { Mean }=5\end{array}$ \\
\hline Rating & Frequency (\%) & Frequency (\%) & Frequency \\
\hline S. A & $160(33.07 \%)$ & 0 & 0 \\
A & $308(63.63 \%)$ & 0 & 0 \\
D & $16(3.30 \%)$ & 0 & 0 \\
S. D & 0 & $9(100 \%)$ & $9(100 \%)$
\end{tabular}

Note: S.A =Strongly Agreed, A =Agreed, D = Disagreed and S.D = Strongly Disagreed

However, all the 9 circuit supervisors and 9 principals strongly disagreed that supervision based on mutual relationship are preferred. This supports Duffy's (1997) version of supervision which is based on rigid and formal supervision.

Table 8 shows that all the research participants strongly agreed that teachers' knowledge and skills are important resource to improve students' achievements. This indicates that teachers' knowledge and skill have a positive influence on students' academic achievements. This implies teachers should be knowledgeable and skillful in their pedagogy to improve students' academic performance. Izumu, et ajl., (1999; 2002), Vagas and Laat (2003), Rivkin, et al., (2004), and Hanushek (2005) further assert that teachers 'knowledge and skills have enormous impact on students' academic achievements. This supports the assertion that purports teachers' performance as being the key determinant of students' academic achievements. 
Table 8: Teachers' knowledge and skills as important resources for students' achievements

\begin{tabular}{cccl}
\hline & $\begin{array}{c}\text { 484 Teachers } \\
\text { Mean }=1\end{array}$ & $\begin{array}{c}\text { 9 Principals \& Assistants } \\
\text { Mean }=1\end{array}$ & $\begin{array}{c}\text { S Supervisors } \\
\text { Mean }=1\end{array}$ \\
\hline Rating & Frequency & Frequency & Frequency \\
S. A & $484(100 \%)$ & $9(100 \%)$ & $9(100 \%)$ \\
A & 0 & 0 & 0 \\
D & 0 & 0 & 0 \\
S. D & 0 & 0 & 0 \\
\hline
\end{tabular}

Note: S.A =Strongly Agreed, A =Agreed, D = Disagreed and S.D = Strongly Disagreed

\section{Key Research findings}

The majority of teachers preferred collegial system of supervision. This finding tallies with Cogan (1973) who observed that it is important to create conditions that will make the teacher comfortable during the supervision process. This implies when supervisor and supervise have cordial relations, there are high chances of the teacher feeling comfortable during the supervision process. It is also contended that when teachers are aware that the roles of supervision is to improve their professional development, they are likely to view the classroom observations positively, but where the views of teachers on supervision are negative, it is likely that the teachers may view supervision as the platform for the supervisor to attack him/her (Beach and Reinhartz, 1989). In a study of supervisory behaviour and teacher satisfaction Fraser (2000) found that most teachers preferred immediate discussions with their supervisors about the lessons observed. They also expected the supervisor to be caring, understanding and helpful. The relationship between the teacher and the supervisor was expected to be collegial rather than authoritarian. Teachers in this study confirmed Fraser's (2000) assertion. Most of them indicated that they preferred immediate post instructional discussion. They revealed that this helped them to have a rough idea of what the supervision report would look like. They also added that during this discussion session, weak and strong points of the lesson were highlighted. Teachers also said they welcomed constructive criticism from the supervisor as it helped them to improve on their teaching methods.

Evidence gathered from the study points to the fact all the supervisors preferred the formal rule-based of supervision. This is in line with the assertion that some heads have been seen as very autocratic in their supervision, making all other players, including students taking the 'back seat'. This tallies with findings that more than a few authorities in the area of supervision recommend collegial processes as options for supervision of teachers (Glatthorn, 1990; Sergiovanni \& Starratt, 1993; Sullivan \& Glanz, 2000). 
The result of participants' view on teachers' performance and its bearing on students' academic was significant and in favour of Ebiringha's (1987) findings which indicated that instructional process and supervision make a difference in students’ performance.

\section{Conclusion and Recommendations}

The responses from teachers took sharp opposing position to those of supervisors. This means the teachers preferred collegial supervision and the supervisors preferred formal rule based supervision. While the teachers supported the use of mutual relationship supervision, the supervisors supported formal rules based supervision. It may be concluded from the results of the study that supervisors support supervision based on formal rules and majority of the teachers support collegial supervision. This means that to ensure teachers' commitment to instructional supervision in technical schools and other analogue institutions, supervisors should use hybrid instructional supervision type. Thus, supervisors should not only base their supervision on formal rules but blend it with collegial supervision.

Also, all the supervisors and the teachers agreed that improve teacher performance has a direct link to improvement in students' academic achievements in schools.

Based on the findings as well as conclusions, the research puts forth the following recommendations to enhance quality instructional delivery: First, formal rules and mutual relationship supervision should be encouraged to make teachers to be involved and committed to improving instructional delivery. Second, School supervision should be implement and tailored to enhance teacher professional development and progress. Thus, it is important for supervisors to use supervision for professional reason and not to victimise teachers or to settle old grudges that have nothing to do with the education of the child. Also the Vocational and Technical Education and other stakeholders should increase the number of workshops for instructional supervisors which would keep supervisors abreast with current supervisory trends.

\section{References:}

Al-Hamdam, J. M. \& Al-Yacoub, A. M. (2005). Evaluation of section heads’ performance at Kuwait secondary school. The International Journal of Educational Management.

Baafi-Frimpong, S. (2002). Educational management and administration.

Cape Coast, Ghana: Graphic Communications Group Publishers

Badu-Nyarko, S. K. (2009). Learning Patterns of Secondary School students in Ghana: Implications for post-secondary distance education. Journal of Literacy and adult Education in Ghana. 4(1),162-174. 
Bamroongraks, W. (1996) 'The role of the Thai inspectorate in the management, monitoring and supervision of the teachers' in: ACEID, op. cit., pp. 252-254.

Best, J. W., \& Khan, J. V. (1998). Research in Education. (8th Ed.) Boston: Allyn and Bacon.

Beach, M and Reinhartz, B. (1989). Supervision: Focus in Instruction. New York: Harper and Row Publishers.

Bays, D. A. (2001). Supervision of special education instruction in rural public school districts: A grounded theory. Doctoral Dissertation. Faculty of the Virginia Polytechnic Institute and State University.

Campbell, R. F., Bridges, E. M. \& Nystrand, R. O. (1977). Introduction to education administration ( $5^{\text {th }}$ ed.) Boston; Allyn \& Bacon.

Campanile, C. (2004). Teacher attrition and retention ( $2^{\text {nd }}$ ed.) New York, USA, Uni-Foundation Publishers.

Cogan, M. L. (1973). Clinical Supervision. Boston: Houghton Mefflin Company.

Daresh, J.C.(2001).Supervision as Proactive Leadership. USA: Waveland Press.

Duffy, F. M. (1997). Knowledge work supervision: Transforming school system into high performing learning organizations, The International Journal of Educational Management, Volume 11; 26 - 31

Ebiringha,O.(1987):Supervision, a key to improvement in an organization: Nigeria Institute of Management. Journal of Educational management. 8(5) P $124-127$.

Feistritzer, C. E. (1999). The making of a teacher: A Report on teacher preparation in the U.S.A. Santa Fe: NM: National Centre for Education Information.

Fischer, O (2008). On analogy as the motivation for grammaticalization, studies in Language. Cambridge University. 336 - 382

Frazer, K. (2000). Supervisory Behaviour and Teacher Satisfaction. Journal of educational Administration 18(2) P $224-227$.

Gentile, J. (1988). Behavior with support in the classroom $\left(1^{\text {st }} \mathrm{ed}.\right)$. Virginia, USA: Practice Publications.

Ghana Education Service, (2009). Roles and responsibilities standards for inspectors \& Circuit supervisors, GES, Inspectorate Division

Ghana Education Service (2009 May). Roles and responsibilities standards for teachers, GES, Inspectorate Division.

Glatthorn, A. A. (1990). Theories of supervision: Introduction. In, G. R. Firth \& E. F. Pajak, (Eds.), Handbook of research on school supervision. pp. 1029-1031. New York: Macmillan. 
Goldhammer, R. (1980). Clinical Supervision. Special Method for the Supervision of Teachers. New York: Holt, Rinchart and Winston.

Goldhaber, D. \& Hansen M. (2008). Assessing the stability of measured teacher performance. Centre on Reinvesting Public Education Working Paper (2008). NewYork, U.S.A: Sage

Goldhaber, D. D., \& Brewer, D. J. (2000). High school teacher certification status and Student achievements. Educational evaluation and policy analysis, New York, U.S.A; Sage

Hanushek, A. E. (2005). The economics of school quality. German

Economic Review 6(3) 269 - 286

Heneman, H.H., Milanowski, A.T., Kimball, S.M., \& Odden, A.R. (2006). Standards-Based teacher evaluation as a foundation for knowledge and skillbased pay Philadelphia, PA: University of Pennsylvania Press.

Hersey, P. \& Blanchard, K. H. (1988). Management of organizational behavior ( $5^{\text {th }}$ ed.). New Jersey: Prentice-Hall.

Joyce, B. \& Weil, M. (1986). Models of teaching, New Jersey: Prentice Hall.

Kilminster, SM, Jolly B, Van der Vleuten C. (2007). A Framework for Training Effective Supervisors. Med Teac 24: 385-389.

Lance T. I., \& Williamson M. E. (2002). Teacher quality; Hoover Institution Press

Lee, H. P. (2006). Reflections on improving teacher performance through online learning, Hong Kong; APERA.

Leigh, A. \& Mead, S. (2005). Lifting teacher performance (Policy Report), Sydney: Progressive Policy Institute Press

Mabey, C., Salaman, G. \& Storey, J. (1998). Human resource management: A Strategic Introduction, $2^{\text {nd }}$ ed., Oxford: Wiley-Blackwell press

Mankoe, J. O. (2007). Quality assessment of educational reform in Ghana, Madina-Accra: Progressive Star Publishers

Mattson \& Ivancevich, (1999). Management and organizational behavior classics, $7^{\text {th }}$ ed., U.S.A.; Irwin/McGraw-Hill Press

McCaffrey F. D., Tim R., Sass, J. R. \& Lockwood, K. M. (2009). The intertemporal variability of teacher effect estimates. Education Finance \& Policy, 572 - 606 .

Mtetwa D. K. J. \& Thompson J. J. (2000). Towards decentralised and more school-focused teacher preparation and professional development in Zimbabwe: the role of mentoring, Journal of In-Service Education, 311- 328 Nir, E. A. (2008). The impact of school-based management on supervision instructors' professional consideration, The International Journal of Educational Management, 49 - 58 
Oduro, G. (2008). Increased enrolment does not mean quality education [Electronic version]. Ghana News Agency. Retrieved from http:news.myjoyonline.com/ education/200809/20151.asp.

Opare, J. A. (1999). Academic Achievement in Private and Public Schools: Management makes the difference. Journal of Educational Management, 2 Pecheone, R. L. \& Chung, R. R. (2007). Evidence in education, The performance assessment for California teachers (PACT), Journal of Teacher Education, 22 - 36.

Prince, C., Schuermann, T.J., Guthrie, J.W., Witham, T.J., Milanowski, A.T. \& Thorn, C.A. (2008). Research synthesis; Questions specific to performance pay; Centre for Educator Compensation Reform

Rivkin, S., Hanushek, E. \& Kain, J. (2004). Teachers, schools, and academic achievements, Econometrica, 417 - 458

Schacter, J. \& Thum, Y. M. (2004). Paying for high and low-quality teaching, Economics of Education Review, 411 - 430

Stevenson, W. (2006). Operations management, $8^{\text {th }}$ ed., McGraw Hill, U.S.A; P.U. publishers.

Sergiovanni, T. J., \& Starratt, R. (1993). Supervision: A redefinition. New York: McGraw-Hill.

Richardson, J., Tate, S., Leonard, O. \& Paterson, J. (2003). Implementing clinical supervision for complementary therapy: an evaluation, school of integrated health, University of Westminster.

Vagas, E. \& Laat, J. D. (2003). Do differences in teacher contracts affects student performance, evidence from Togo, NBER Working Paper 